\title{
Exploration of the Classic Occupation Career Education Resource Sharing System in College Based on the Network
}

\author{
Gao Yan* \\ JiLin Engineering Normal University, Changchun, \\ Jilin, China \\ e-mail: arnold0110@ sina.com \\ * Corresponding Author
}

\author{
Zhang $\mathrm{Na}$ \\ College of Art and Design \\ Shenyang Jianzhu University \\ Shenyang, China
}

\begin{abstract}
This document explains and demonstrates how to prepare your camera-ready manuscript for Trans Tech Publications. The best is to read these instructions and follow the outline of this text. The text area for your manuscript must be $17 \mathrm{~cm}$ wide and $25 \mathrm{~cm}$ high $(6.7$ and 9.8 inches, resp.). Do not place any text outside this area. Use good quality, white paper of approximately $21 \times 29 \mathrm{~cm}$ or $8 \times 11$ inches (please do not change the document setting from A4 to letter). Your manuscript will be reduced by approximately $20 \%$ by the publisher. Please keep this in mind when designing your figures and tables etc. There should be 60 pounds of space above the caption and 6 pounds of space below it before the text continues. There should be 6 pounds of space above other information of the author, such as name, address and so on. Corresponding author is optional.
\end{abstract}

Keywords-Occupation ; Career Education ; Classic Resource; Sharing System; Network.;

\section{INTRODUCTION}

In 2011, "the Ministry of Education and Ministry of Finance on the" Twelfth Five Year Plan "period to implement" the undergraduate teaching quality and teaching reform "opinion" and "the implementation of opinions" of the Ministry of education of national highquality course construction requirements: To firmly establish the initiative for the social service consciousness, to carry out a full range of services. Occupation education resources such as the exemplary major should be opened training base, professional model, famous teachers and classes, high-quality courses etc. So they can provide the occupation education and skill training for all types of students.

Higher requirement was put forward to college for the actively serve the society by recently policy. The requirement of the opening teaching resource is very clear and specific. It's necessary to develop the occupational career education to provide the excellent teaching resource to satisfy the demand of the teaching reform.

\section{CURRENT DEMAND}

\section{A. Demand Of high-quality resource occupation career education of college students}

It has a history of one hundred years of abroad that the occupation career education has formed a special theoretical system by putting forward to the theory concept and completing it. The domestic universities also gradually introducing foreign occupation career planning theory and occupation career guidance thought, few universities set up the occupation career guidance center in the school, providing career guidance comprehensive service to students. The college students' career guidance is still in the primary stage in the theory and practice by the relatively started late since the late of economic system reform.

College students pay more attention to the self occupation career development and more management, they aware of the importance of the establishment of their own development goal, they are glad to establishment of long-time development target and table by thinking about the relationship of future ideal occupation and their major.

The aim of the occupation and career education is to stimulate students' occupation career development consciousness, to establish a correct concept of employment and to guide students to construct their own occupation career planning by understanding the relationship between their major and their future occupation, so they can respond to their future career. It's a logical starting of the occupation career education resources to provide quality products for the increasing urgent demand, it's also an urgent requirement of college should output the excellent occupation career education so it can satisfy the demand of students' and the society by college education system and training system and the guidance system in network monitoring management sharing platform. The colleges should take the open to the society boutique resources occupation career education as their mission and responsibility.

\section{B. Demand of college occupation career education teaching and practice teaching reformUnits}

Occupation career planning education in China has just started pushing by the National Ministry in order to 
comply with the requirements of the socialist market economy and is currently in the perceptual stage of development. The development path of occupation career planning education is along with the knowledge educationquality education-choosing a career and obtains employment-innovation-entrepreneurship education.

Study of the occupation career planning education is transiting from analysis of the concept, origin, expounding the importance of education to education, teaching, principle, method, path and pattern. We should take through the problems of current college occupation and career planning education and actively explore the contraction of sharing system of college students' career planning education. To set the guidance from the specialized agencies, establish the professional guidance teachers, promote the sharing platform service full coverage of the network, set up the course system of the scientific and reasonable construction, set up a complete career planning theory and practice teaching system and carry out a occupation career planning education of whole process, personalized, marketing so put forward the effective path of college students' occupation career planning education sharing system.

The high-quality resource sharing system of occupation career education is the need of culturing excellent applied and technical talent; it's a very important part of the talent training and practicing system. It's irreplaceable in guiding students to link theory with practice, raising the students' practical ability and innovation ability. The construction of high-quality resource sharing system of occupation career education will effectively promote the reform of experiment teaching content, teaching system, teaching method and means. It's very important to improve the quality of students and raise more high level occupation skill talents.

\section{COLLEGE HIGH-QUALITY RESOURCE OF OCCUPATION CAREER EDUCATION SYSTEM REFORM}

In recent years, Japanese universities take a curriculum reform according to the school and professional characteristics. Such as the Mustachio University established occupation career education curriculum system composed of occupation career education pandect which including the basic course, self understanding course and social understanding course, and single theory which involving professional courses in all fields.

In addition, University and society courses of the Hokkaido University, occupation and self realization course selection of Hiroshima University, Wakayama University occupation society and qualification system course. Students of these universities master the basic knowledge of society and social skills which can help students better understand the social and adapt society.

The opening occupation career course resource construction and operation showing a variety patterns and ways which beginning to "open education" upgrading in America. Open occupation career education resources construction mode, application mode and operation develop from displaying their teaching resources to provide network course for teaching, continuing education and the social learning. Those schools that open to all the occupation career course syllabus and teaching plan on the website are supervising the quality of curriculum autonomy with the simple and effective way. The construction of the domestic occupation career education excellent resources system should draw lessons from foreign occupation career education mature theory teaching and practice teaching system, here take my school as an example to explore sharing constitute and reform of system resources occupation career education quality.

\section{A. Background of the quality occupation career education resource sharing system reform}

The development of occupation career education is an important way to promote economic development, promoting employment, improve people's livelihood and a key to ease the contradiction between labor supply and demand structures.

Occupation career education focus on the occupation skill and employment ability and students' occupation moral. The regulations is employee based on the training, to establish and perfect the theory and practice of occupation career education system and encouraging graduates continuing learning, to improve the employment ability of graduate's occupation and broaden the channel of continue learning.

\section{B. Contents of the quality occupation career education resource sharing system reform}

Occupation career education excellent resource sharing system reform is to improve the teaching resource center and occupation career education training center for students, , as shown in figure 1.

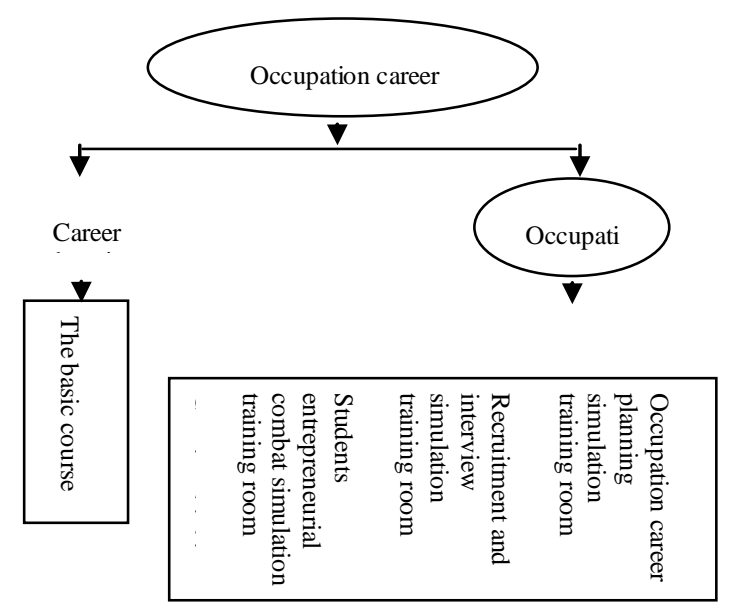

Firstly we should construct the teachers' occupation career education of teaching resource center: some basic resources are nursery to be constructed completely, the course introduction, teaching outline, teaching calendar, evaluation methods and standards, study guide, teaching plan (presentation), the problem sets, exams, example, courseware, teaching case, media material, learning manual, electronic materials, experiment and practice training, simulation training, experimental animation, common problems, expert lectures, students' works, documents, terms, introduction and teaching video course should be involved. At the same time, vigorously curriculum resources should be developed. In addition, the case library, including library, lecture material database, knowledge retrieval system, demonstrating the virtual 
simulation experiment training system, database system, operation system, online self testing examination system, teaching software and other auxiliary resources also should be developed.

The second, the constriction of students' career planning education training center should involve laboratory and some sets of experimental instruments. There should set occupation career planning simulation training room, recruitment and interview simulation training room, training room, combat simulation of entrepreneurship students innovative thinking ability of training room, training room, ERP sand table simulation training room, student venture evaluation of students' innovative combat simulation training room, training room in the center.

\section{RESULTS}

\section{A. To develop a new high-quality college career education sharing system}

The new high-quality college career education sharing system namely to take the course construction, teachers team construction, evaluation system establishment, practice training implementation, network sharing service as a whole. The five factors mutual support and complement each other that the curriculum structure is the guidance, the teachers' team construction is pilot and security, job evaluation is a means, practice is the carrier, network service is the developing direction, they are with strong scientific and practical in practice.

The aim is to guide the students to understand the method of occupation career planning, guide the students to plan their occupation career in advance during the college, to adapt to the social development and changes in every aspect of the occupation target, comprehensive quality, mental status, to definite the occupation development goals so to prepare a adequate knowledge and skills according to their own development goals, then they can master career skills and techniques and improve the skills and social cognitive ability through the system in order to get a space for one person in the fierce occupation post the competition.

At the same time, network tutoring should be taken to the students about the working process of the occupation career development, and try to achieve beneficial for college graduates occupation career self-monitoring, self management and self development.

\section{B. To improve the occupation career education theory teaching and practice system}

In theory teaching, occupation career education should introduce "six dynamic teaching mode", that means the task driven, teaching, interest drive, transmission affects reflection, practice, operation pull linkage.

The six dynamic teaching mode is through the arrangement of each class is reasonable in theory in the teaching content to make the students understand the teaching task to improve the teaching content, teachers should know about the knowledge and skills students should master before the class in the teaching process through each course. Teachers should ensure the students fully integrate into the class and try to increase interest in learning. Teachers should profound consideration about each class so can reflect the learning effect, after the completion of the theoretical teaching for students, lead them to actively participate in practice, such as through the occupation career planning course book design to help students better understand the content of the course. Each time after the class teachers should arrange necessary homework, teachers provide students with regular counseling and coaching through the network so can help them solving the practical problems and understanding the next course content so let the students prepare the next course. Colleges should put the occupation career education with professional education and comprehensive quality education for improving their employment and entrepreneurship capacity.

In addition, colleges should strengthen the education practice, highlight the effectiveness, improve the teaching practical ability, innovation ability and the ability of teaching reflection. The basic resources course should be completed construct, while develop the distinctive curriculum resource. By the form of career training, human-computer interaction, micro teaching, experience to explore the development rules of occupation career and construct the characteristic occupation education practice teaching system to provide the conditions to the graduates in the occupation career management to facilitate the timely monitoring and evaluation in the work.

The establishment of the education system, not only can provide a high level experimental teaching and academic competition platform for college students, it also provide the open network environment so the college graduates' can better manage their occupation career, at the same time, it also provides the scientific research and test platform for teachers, provide the necessary conditions for the discipline construction, lay a solid foundation for the cultivation of high quality technical talents of application.

\section{C.To build a professional teachers guidance and students' self-management}

Through the assistant of the counselors, students can actively planning career self cognition research and formulate reasonable career planning, finally they get the self adjustment ability and finally promote students' career development goal activity.

The aim is guide the students to survey the internal relationship between occupation and life development by a wild field of vision and evaluate the various development resources the students owned so they can confirm how to select and plan their occupations so to realize the effective interaction by promoting the development of individual autonomy between the individual and society.

\section{CONCLUSIONS}

Obviously, through the occupation career education sharing quality resources system introduced to the college can change the single training method of current training such as myopic, narrow, single training method and complete students' comprehensive development.

At the same time, we can better guide the college students' occupation career development by improving the college high-quality occupation career planning education sharing system and complete current fragmented, isolated, the fault type of student management system, so to realize the continuous information and sharing, can make better career development counseling for students, let them have 
a clear plan for their own career development, to help students to clear their own position, so they can find a suitable location in the future work and life.

\section{REFERENCES}

[1] Liu Wenming. Higher vocational colleges to provide quality teaching resources to the society to explore $[\mathrm{J}]$. occupation technology education, 2012 (35):78 -80.

[2] Cui Ying. College student occupation career planning education system research [D]. Beijing: Capital University of Economics and Business, 2012:1-6.

[3] Yang Li. The occupation career planning education system [D]. Shanghai: Fudan University, 2009:6-10.

[4] Ceng Meiying, Dou Xiuming. The college students' occupation planning [M]. Beijing: Beihang University press, 2008:58-62.
[5] A.G. Watts.Ronald G.Sultana.John Mc Carthy.The inolvement of Edul vocat GUidance,2010(10)

[6] Greenhnaus J H.Career Management[M].Hinsdale.Dryden Press, 2011.

[7] Morgan M.Manahing career development[M].Newyork:van Nostrnad,

[8] 2011

[9] Walker J W.Human resource Planning[M].New York: Mc GrawHill, 2011.

[10] Le Petit Larousse, Paris: LAROUSSE, 2005

[11] Udge, TA., Locke, E. A ., Durham, C . C . \& Kluger Dis A N, Positional effects on job and life satisfaction: The role of core evaluations, Journal of Applied Psychology, 83 ( 1 ) 1998 